\title{
Seasonal occurrence of Loricate Choanoflagellates in Danish inner waters
}

\section{Thomsen, Helge Abildhauge; Nitsche, Frank; Richter, Daniel J.}

\section{Published in:}

Protist

Link to article, DOI:

10.1016/j.protis.2016.09.002

Publication date:

2016

Document Version

Version created as part of publication process; publisher's layout; not normally made publicly available

Link back to DTU Orbit

Citation (APA):

Thomsen, H. A., Nitsche, F., \& Richter, D. J. (2016). Seasonal occurrence of Loricate Choanoflagellates in Danish inner waters. Protist, 167(6), 622-638. https://doi.org/10.1016/j.protis.2016.09.002

\section{General rights}

Copyright and moral rights for the publications made accessible in the public portal are retained by the authors and/or other copyright owners and it is a condition of accessing publications that users recognise and abide by the legal requirements associated with these rights.

- Users may download and print one copy of any publication from the public portal for the purpose of private study or research.

- You may not further distribute the material or use it for any profit-making activity or commercial gain

- You may freely distribute the URL identifying the publication in the public portal 


\section{Accepted Manuscript}

Title: Seasonal Occurrence of Loricate Choanoflagellates in Danish Inner Waters $<!-<$ RunningTitle $>$ Loricate Choanoflagellates in Danish Inner Waters $<$ /RunningTitle $>->$

Author: Helge Abildhauge Thomsen Frank Nitsche Daniel J. Richter

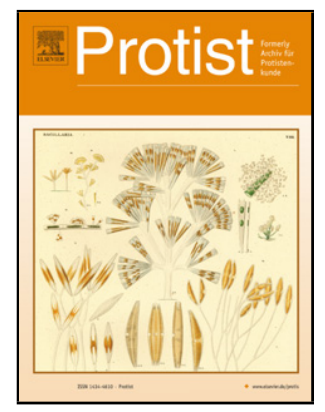

PII: S1434-4610(16)30059-1

DOI:

Reference: http://dx.doi.org/doi:10.1016/j.protis.2016.09.002 PROTIS 25548

To appear in:

Received date: $\quad 8-6-2016$

Accepted date: $\quad$ 24-9-2016

Please cite this article as: Thomsen, Helge Abildhauge, Nitsche, Frank, Richter, Daniel J., Seasonal Occurrence of Loricate Choanoflagellates in Danish Inner Waters.Protist http://dx.doi.org/10.1016/j.protis.2016.09.002

This is a PDF file of an unedited manuscript that has been accepted for publication. As a service to our customers we are providing this early version of the manuscript. The manuscript will undergo copyediting, typesetting, and review of the resulting proof before it is published in its final form. Please note that during the production process errors may be discovered which could affect the content, and all legal disclaimers that apply to the journal pertain. 


\section{ORIGINAL PAPER}

\section{Seasonal Occurrence of Loricate Choanoflagellates in Danish Inner Waters}

\section{Helge Abildhauge Thomsen ${ }^{\mathrm{a}, 1}$, Frank Nitsche ${ }^{\mathrm{b}}$, and Daniel J. Richter ${ }^{\mathrm{c}, \mathrm{d}}$}

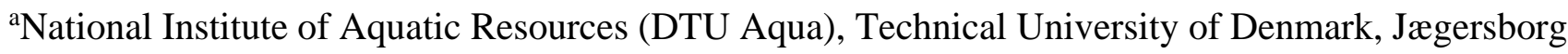
allé 1, DK-2920 Charlottenlund, Denmark

bZoological Institute, General Ecology, University of Cologne, Zülpicher Str. 47b, 50674 Cologne, Germany

'CNRS, UMR 7144, Station Biologique de Roscoff, Place Georges Teissier, 29680 Roscoff, France dSorbonne Universités, Université Pierre et Marie Curie (UPMC) Paris 06, UMR 7144, Station Biologique de Roscoff, Place Georges Teissier, 29680 Roscoff, France

Submitted: June 8, 2016; Accepted September 24, 2016

Monitoring editor: B. S. C. Leadbeater

Running title: Loricate Choanoflagellates in Danish Inner Waters

${ }^{1}$ Corresponding author; e-mail hat@aqua.dtu.dk (H. Thomsen). 
It is a trend in loricate choanoflagellate research that our knowledge of species diversity is insufficient in terms of understanding annual successional changes at any specific locality, whereas there is a fairly decent coverage worldwide - at least in more coastal realms - in terms of biodiversity within more narrowly defined time windows. To help address this knowledge gap, we have compiled all available loricate choanoflagellate occurrence data from Danish sampling sites covering an overall time span of close to four decades. The close to 100 samples analysed have a good annual coverage and they encompass in total more than 50 species. We demonstrate clear successional trends among well-defined clusters of species. A large contingent of 'non-native' species, which are in a global context largely considered part of the loricate choanoflagellate warm water community, occurred in September 2014 samples from the Baltic Sea entrance, i.e. the Sound between Denmark and Sweden. While the occurrence of these species is likely due to a large inflow of southern Atlantic water, we also discuss whether the findings may instead reflect recent and more permanent climate change-induced alterations to choanoflagellate biodiversity in inner Danish waters.

Key words: Loricate choanoflagellates; seasonality; diversity; Western Baltic.

\section{Introduction}

Choanoflagellates are unicellular or colonial eukaryotes found ubiquitously in aquatic habitats, where they occupy niches in both pelagic and benthic communities. They are heterotrophic phagotrophs that feed on bacteria and other picoplankton aided by a filtering device comprising a collar of microvilli surrounding a single apical flagellum. The loricate choanoflagellates (Acanthoecida) are characterised by species-specific extracellular structures constructed from silicified rod-like units. These particular organisms, with approximately 115 species described at present, are almost 
exclusively found in brackish and marine habitats, and they constitute from time to time an important ecological component within the microbial loop trophic pathway (Azam et al. 1983). The choanoflagellates which are phylogenetically recognized as a sister group to the Metazoa have recently been extensively surveyed by Leadbeater (2015).

The vast majority of publications centered on loricate choanoflagellate diversity represent snapshots of community structure with a limited resolution in space and, more particularly, time. A seasonal occurrence aspect is thus addressed in a very limited number of publications, e.g. Marchant and Perrin (1990), Smith and Hobson (1994), Tong (1997a), McKenzie et al. (1997), Menezes (2005) and Samuelsson et al. (2006). In order to add to our understanding of loricate choanoflagellate seasonal occurrence patterns in northern latitude temperate waters, we present here details of our compilation and analysis of data from Danish waters. Special attention is also devoted to the loricate choanoflagellate biodiversity encountered during two recent field campaigns (September 2014 and February 2015).

The target area covered here is Danish fjords and sounds in the vicinity of Copenhagen. Their strategic position in between the brackish Baltic Sea and a full saline North Sea, in combination with a pronounced annual variation in temperature, ensures that these habitats will through time offer both species rich and diverse loricate choanoflagellate communities. We have compiled all available data on the occurrence of loricate choanoflagellates in Zealand coastal waters. Most datasets originate from the innermost broad of the Isefjord, the southern Kattegat and the Sound off Elsinore (Fig. 1) and thus represent a relatively geographically homogeneous sampling site matrix, which in turn allows us to provide relevant insight into seasonal occurrence patterns of individual taxa. Although all sampling sites are by default coastal, the dynamic nature of the seas around Zealand, including major and frequent bidirectional water exchange between the Baltic Sea and the North Sea, will ensure that the species communities encountered will at all sites comprise a mixture of near shore and open ocean species. The data matrix encompasses 93 samples and a total of 53 species. There is 
one limitation to the interpretation of our dataset that we briefly discuss here. While the technique of identifying loricate species by light microscopy in 'air-mounted' coverslip preparations is appropriate for recording species richness, it is only capable of producing relative (and not absolute) abundance data for the components of the species community, because the nanoflagellate concentration technique applied is not quantitative.

\section{Results and Discussion}

\section{Main Sites Explored - Environmental Parameters}

The data presented here come from various sites within a $60 \mathrm{~km}$ radius of Copenhagen (Fig. 1). Each of the main sites (i.e. the Isefjord, a permanent station in the southern Kattegat, and a station in the Sound outside Elsinore) are briefly characterized below.

The Isefjord system maintains a fairly high salinity $(>18)$ due to a frequent exchange of water through the entrance to the Kattegat and also because of a rather limited drainage area. The temperature varies annually typically between 0 and $20^{\circ} \mathrm{C}$. The Isefjord system is very shallow $(<10$ $\mathrm{m}$ ) and characterized by a water column that rarely becomes stratified (Fig. 2A). The water depth at a permanent southern Kattegat station ('HAV90') sampled during 1988-89 exceeds 20 m, and the water column is here distinctly temperature and salinity stratified during the summer months (Fig. 2B). The Sound between Denmark and Sweden is a strongly stratified water mass with a top layer of brackish water with a salinity that typically ranges from 10-20, and a bottom layer of colder and more saline water (20-32). Vertical profiles of temperature and salinity are shown in Figure 2C for collections made September 2014 and February 2015. The Sound is a highly dynamic strait which is characterized by rapid changes in current direction and magnitude. 


\section{Seasonal Trends in Species Occurrences}

The shade matrix (Fig. 3) is a valuable tool in terms of providing an immediate overview of the possible existence of communities of loricate choanoflagellates with seasonal preferences. The interpretation of the matrix is here aided by the addition of vertical and horizontal hierarchical lines grouping sampling events and species according to levels of dissimilarity. The most prominent bifurcation of sampling events (Fig. 3; thick line) separates a cluster of mostly summer and early autumn samples from others mostly from the winter-spring period. When examining the large-scale trends with reference to clustering of species the main bifurcation (Fig. 3; thick line) separates our late September 2014 consortium collected in the Sound from the remaining species. These particular samples were characterized by an unusually high species diversity ( $>30$ taxa) and the presence of a contingent of what must be considered, in a historical context, to be 'non-native' species (Fig. 3 cluster A) to Danish waters (i.e. Cosmoeca ceratophora, C. ventricosa B, Apheloecion quadrispinum, A. pentacanthum, Platypleura infundibuliformis, Stephanacantha campaniformis and others). There are two prominent species clusters of open water forms pertinent to each of the main seasons identified above. The autumn cluster (Fig. 3 cluster B) features Calliacantha simplex as its most prominent member in terms of relative abundance, and additionally comprises Nannoeca minuta, Parvicorbicula superpositus, Cosmoeca norvegica, Acanthocorbis campanula, and also Crinolina isefiordensis. In contrast, Calliacantha natans in particular, but also Pleurasiga minima and Cosmoeca ventricosa are core members of the winter-spring open water community (Fig. 3 cluster C). Whereas the above two clusters tend generally to consist of forms that are 'oceanic', the cluster D (Fig. 3) encompasses forms that occur most frequently during the summer months and most often in near-shore samples (Diaphanoeca grandis, Stephanoeca elegans, S. paucicostata, S. diplocostata, S. apheles, Acanthocorbis apoda, and Didymoeca costata). The species cluster E (Fig. 3) comprises mostly oceanic species that are adapted to cold water environments (Bicosta minor, B. spinifera, Calliacantha longicaudata, Parvicorbicula socialis and Pleurasiga reynoldsii). 
Acanthocorbis unguiculata also belongs to this cluster, but deviates in that it generally occurs in samples from near-shore sites. The last cluster of species highlighted (Fig. 3 cluster F) represents genuine winter forms in Danish waters with an open ocean prevalence, i.e. Diaphanoeca sphaerica, Saroeca attenuata, Parvicorbicula circularis, P. quadricostata, P. manubriata and Bicosta antennigera.

The similarity among species in terms of seasonal appearance is further illustrated (Fig. 4) in a series coherence plots (index of association) where the pattern of occurrence is plotted against time (Julian days). The species abundance is expressed as a percentage of total relative abundance for that species overall. These line plots are grouped together in species sets which are statistically indistinguishable internally but significantly different between sets (based on SIMPROF similarity profile analysis; Clarke et al. 2014). The plots clearly display seasonal distribution trends for a large number of taxa (labels of individual graphs correspond to groups identified in Fig. 3A-F). The majority of the species in group A represent the 'non-native' species community that was encountered late September 2014 at stations in the Sound (see below for further details). Spinoeca buckii was originally described from NE Greenland (Thomsen et al. 1995) and is known to have its main distribution within cold water realms. The observations of this species in February and March are thus at temperatures typical for the species, whereas the specimens observed in Sept. 2014 appear in species clusters that are, based on our present knowledge, much less typical for the species. Both Pleurasiga echinocostata and Crucispina cruciformis were sporadically observed in other samples than those of Sept. 2014 from the Sound. The cumulative appearance of the multispecies occurrences depicted in group B is almost that of a dome-shaped curve extending from May to October with a peak during the summer period (June-August). This general pattern is slightly disturbed by single relatively large scale occurrences of Parvicorbicula superpositus and Cosmoeca norvegica, and even more so by the episodic occurrences of Nannoeca minuta. Nannoeca minuta is among the smallest of the loricate choanoflagellate species present in Danish waters and thus the inherent difficulties in 
detecting and identifying this species may influence the occurrence pattern recorded. The plots for groups B and C should be viewed together because the occurrence patterns here illustrated are almost exactly complementary in terms of seasonal timing. When Calliacantha simplex is not present (B) the dominant species of Calliacantha in our waters is C. natans (C). The highly distinct occurrence patterns of Calliacantha natans and C. simplex are further illustrated in Figure 5, which is a simple plot of relative abundance over time. Although exceptions exist (e.g. around Julian day 300) the overall pattern is unmistakably such that when one species is present, the other is absent from our samples. Whereas both Calliacantha natans and Pleurasiga minima occur from October to May, it appears that Cosmoeca ventricosa in Danish waters is primarily confined to the period October to December. Group D represents another set of 'summer' taxa (see also (B)), but with the potential to occur throughout the year (e.g. Acanthocorbis apoda, Diaphanoeca grandis, Stephanoeca diplocostata). Species clustering in group D are characteristic for the most near-shore habitats. Group E comprises species with episodic occurrences primarily during winter and mostly with high latitude North Atlantic type localities. Calliacantha longicaudata was for almost two decades limited in known distribution to West Greenland sites but is in fact regularly observed in Danish waters when temperatures approach zero degrees (Thomsen 1992). While Bicosta minor is essentially confined to the late autumn season, other species from this cluster peak from January to April. Acanthocorbis unguiculata is a coastal species and thus shares only its seasonal occurrence pattern with the other predominantly 'oceanic' forms. Group F comprises species that predominantly occur during January-March. Acanthoeca spectabilis, Savillea micropora, and S. parva are near-shore coastal forms.

Leadbeater (2015) discusses, based on a compilation of species lists from a variety of locations, the categorization of loricate choanoflagellates with respect to near-shore, intermediate and openocean locations. Our data as presented here, with all habitats sampled treated equally, does not by itself add further evidence in this context. However, some of the species clusters discussed above 
(e.g. 4D) do evidently group together species that share a common preference for coastal versus open ocean habitats.

Tong (1997a) provided seasonal occurrence data of loricate choanoflagellates based on biweekly sampling at a permanent station in Southampton Water (English Channel) from March 1993 to June 1994, and concluded that it was possible to distinguish among four patterns of seasonal occurrence: (1) species present throughout the year, e.g. Calliacantha natans, C. simplex (most abundant during spring), Bicosta minor and Cosmoeca norvegica (the latter two species most numerous in summer), (2) species which were rarely seen (observed in only one to three samples), (3) species which were seen sporadically but more common in spring and summer, e.g. Bicosta spinifera, Pleurasiga reynoldsii, Diaphanoeca grandis and Acanthocorbis unguiculata and (4) species with a seasonal occurrence, e.g. Diaphanoeca undulata (summer) and Pleurasiga minima (winter and spring). Despite the fact that the Southampton list of loricate choanoflagellates is to a large degree overlapping with similar lists from Danish coastal waters (Table 1), there are nearly no shared seasonal occurrence patterns, except for Cosmoeca norvegica and Pleurasiga minima, to be highlighted from a comparison of the two studies. Although a direct quantitative comparison is impossible because of significant differences in analytical approach, seasonality appears to be much more pronounced when examining the Danish material. This may simply reflect that inner Danish waters are exposed to a more continental climate and hence that seasonal extremes and changes in community controlling parameters, such as temperature, are much more pronounced in Danish local waters. Recurrent hydrographic features will contribute to shaping site-specific seasonality patterns observed among any group of planktonic organisms (for example, as a 'seed' source). The region sampled here (with the exception of the innermost Isefjord stations) is in a hydrodynamic context characterized on a daily or weekly time scale by fairly rapid changes in water current direction and physico-chemical parameters, which are bound to create 'noise' when analysing community development at a specific location, in particular because of the geographic proximity of brackish 
water and open ocean communities. A compilation of a large volume of data from different sites, seasons and decades, as carried out here, is on the other hand likely to significantly moderate this element of variability, causing the overall general patterns in seasonality to stand out in a more trustworthy manner. It should be emphasized, although beyond the scope of this paper, that annual variability in biotic parameters such as bacterial and phytoplankton abundance, productivity and diversity may directly or indirectly impact on loricate choanoflagellate successional patterns, as may also fluctuations in e.g. availability in pelagic attachment sites and zooplankton grazing.

To examine the pattern of species richness among samples, we plot the number of species in each individual sample (Fig. 6). While it is not possible to collect exhaustive census data, we are inclined to think that because the same overall technique has been used throughout all forty years of sampling, and also because all microscopy work has been undertaken by the same person, we are able to eliminate some of the issues related to a simple plotting of species per sample. Figure 6, in addition to depicting the species richness data, also indicates the sampling location of each individual data point. The overall range in terms of species per sample is 2-28. A simple average value across all samples amounts to $9.1 \pm 4$, meaning that the vast majority of samples fall within the range 5-13. The single most diverse sample (>28 species) is the Sept. 2014 sample from the Sound $(20 \mathrm{~m})$. We observe a weak overall tendency of a slight decline in species richness during the summer months (Fig. 6).

\section{Species Diversity During Field Campaigns (September 2014 and February 2015)}

While historical data is the keystone component of this analysis of seasonal occurrence patterns, we elaborate here on results added from recent field campaigns, because the occurrence patterns we observed deviate substantially from the established norm within our sampling region. Table 1 summarizes observations made during the September 2014 and February 2015 field campaigns. A total of 45 taxa were encountered, corresponding to approximately one third of all loricate 
choanoflagellate species described worldwide. Data presented in Table 1 also reflect that significant differences in species composition and relative abundance exist both within short geographic distances and when sampling is repeated at the exact same location but with a time interval of a few days. The latter is clearly observed when comparing samples from the Elsinore harbour collected September 2014 with a 3-day interval (Table 1), e.g. when comparing the prevalence of Acanthocorbis apoda on the first day of sampling and the simultaneous absence of Calliacantha simplex. Three days later the harbour community was conspicuously more similar to the open water surface community sampled a few kilometres offshore. The weather conditions prior to our field work had been calm, making it likely that the harbour community had developed independently of the open water community. Significant weather changes on September 21, with rough seas and significant water exchange, similarly explains the marked differences noted when sampling the harbour area within a short interval. Due to the protected nature of the harbour habitat a delay in response to the changed weather conditions must be anticipated.

The September 2014 samples comprised taxa that are typical for the season, i.e. Acanthocorbis campanula, Calliacantha simplex, Cosmoeca norvegica and Parvicorbicula superpositus (cfr. Fig. 4B). However, the $20 \mathrm{~m}$ sample from the Sound (24 Sept. 2014) was unique in terms of species diversity and the presence of a large number of what can best be described as ‘non-native’ species. A collection of LM and SEM micrographs are assembled in Figures 7-8 to document these observations, and each of the taxa is briefly described below. The occurrence pattern of these taxa on a global scale is summarized in Table 2. See e.g. Thomsen and Buck (1991) for a definition of descriptive terms applied below.

Acanthocorbis asymmetrica cfr. (Fig. 7A, J). The lorica is typical for a species in the genus Acanthocorbis. The asymmetrical short posterior stalk is a feature that is shared with A. asymmetrica (Thomsen 1979). However, there are in the latter species two clearly separated anterior transverse costae located well below the junctions between the two anteriormost longitudinal costal strips, as 
opposed to just a single anterior transverse costa observed here (Fig. 7A), which is furthermore intimately associated with the junctions between the ultimate and penultimate longitudinal costal strips. The number of longitudinal costae in A. asymmetrica is 15-17 whereas it is only 9-10 in $A$. asymmetrica cfr. This is most likely a new species of Acanthocorbis that will be formally described in a follow up paper that describes species diversity within the genus Acanthocorbis from the Baltic Sea at large (Thomsen, unpublished).

Apheloecion (Fig. 7B-F). Two species of Apheloecion were observed: A. quadrispinum (Fig. 7B, C) and A. pentacanthum (Fig. 7D-F). Key features of the genus are a small-sized lorica chamber with projecting spines anteriorly, a single transverse costa and a posterior spine or pedicel. The two species observed are differentiated based on the number of longitudinal costae and the position of the transverse costa relative to longitudinal costal strips. In A. pentacanthum, the transverse costa is located midway along the anterior-most longitudinal costal strips (Fig. 7F), whereas in $A$. quadrispinum the length of the anterior spine corresponds to one longitudinal costal strip. Both species of Apheloecion were described from the Andaman Sea, Thailand (Thomsen and Boonruang 1983a) and recordings from elsewhere are rather limited (Table 2). Due to the minuteness of these organisms it is, however, probable that they are critically underrepresented in loricate choanoflagellate surveys at large. However, considering the frequent appearance of specimens in Indian Ocean samples (Thomsen and Boonruang 1983a), these forms are likely to be part of the warm water tropical and subtropical loricate choanoflagellate community.

Cosmoeca (Figs 7I, K-L and 8A). In addition to C. norvegica and C. ventricosa, which are both key members of the northern hemisphere temperate loricate choanoflagellate community, the Sept. 201420 m sample also comprised specimens assigned to C. ventricosa B and C. ceratophora (Table 1). Both of these forms were originally described from the Andaman Sea, Thailand (Thomsen and Boonruang 1984) and whereas observations of C. ceratophora have so far been largely confined to warm water tropical and subtropical seas, the distribution of Cosmoeca ventricosa B indicates a 
much larger temperature tolerance in this species (Table 2). Cosmoeca ventricosa B is similar to C. ventricosa in basic structural details but deviates in having anterior spines terminating in an angled hook (Fig. 8A). Despite being rather minute, these features are also visible via LM (Fig. 7I). Cosmoeca ceratophora is characterized by a conical lorica, two transverse costae and projecting straight spines anteriorly. The distance between the two transverse costae corresponds to $2 \frac{1}{2}$ longitudinal costal strips. Whereas the specimen illustrated in Figure 7K is clearly C. ceratophora, it is possible that the second specimen illustrated (Fig. 7L) might in fact be C. subulata. In this species, also described from the Andaman Sea, Thailand (Thomsen and Boonruang 1984), the lorica is slightly less conical because the second transverse costa is shifted forward by one longitudinal costal strip.

Crucispina cruciformis (Fig. 7G-H,M). This species is easily identified due to the X-shaped configuration of two longitudinal costae (Fig. 7G,H) and the presence of a minute lorica chamber formed by a few, much less solid costal strips (Fig. 7M). Single specimens of C. cruciformis have previously been encountered in samples from Danish waters (Thomsen 1992). However, this is the first time that a 'bloom' condition (3.7\% of all specimens identified within the $20 \mathrm{~m} 24$ Sept. 2014 sample) has been observed. Crucispina cruciformis is widely distributed but is mainly found within the warm water realms of the world's oceans (Table 2).

Pleurasiga echinocostata (Fig. 8B, C). The distinguishing features of this taxon are a conical lorica formed by 7 longitudinal costae surmounted by a single anterior transverse costa (T-joints) and prominent spines at one end of each of the transverse costal strips (Fig. 8B). Single specimens of $P$. echinocostata have previously been encountered in samples from Danish waters (Thomsen 1992), and the type locality of the species is Kilsfjorden, S. Norway (Espeland and Throndsen 1986). The species has also been recorded from a wide range of additional sites (Table 2).

Platypleura infundibuliformis (Fig. 8D-F). The lorica is barrel-shaped and composed of flattened costal strips. There are approximately 10 longitudinal costae, and 3 transverse costae; E- 
joints anteriorly and lorica posteriorly terminated by a tuft of flaring costal strips. The genus Platypleura (Thomsen and Boonruang 1983b) has its main distribution in tropical and subtropical seas. The sampling site of the generic type, P. infundibuliformis, is the Mediterranean Sea (Leadbeater 1974; Bay of Algiers). Single specimens have been previously observed in Danish waters (Thomsen 1992) and also from Kilsfjorden, Southern Norway (Espeland and Throndsen 1986). See Table 2 for additional recordings of this taxon.

Stephanacantha campaniformis (Fig. 8G-H). The lorica is conical and composed of flattened costal strips organized in 6 longitudinal costae which are anteriorly surmounted (T-joints) by a transverse costa. The anterior and posterior lorica chambers are separated by a zig-zag shaped transverse costa. Stephanacantha spp. share the distributional characteristics of Platypleura spp., and also the sampling site of their generic type (S. campaniformis) is from the Mediterranean (Leadbeater 1973; coast of Croatia). This is the first recording of the species from Danish waters. However, it was previously recorded from the region by Espeland and Throndsen (1986; Kilsfjorden, southern Norway). For further recordings see Table 2.

Based on the data presented in Figures 3-4, the 20 m community encountered 24 Sept. 2014 from the Sound (as detailed above and in Table 1) is unique in comparison to all other loricate choanoflagellate samples available to us from Danish waters. It deserves to be mentioned that the same 20 m sample was also rich in species of coccolithophores (Prymnesiophyceae) and that some of the calcified species observed were new recordings to Danish waters (Thomsen 2016). The most obvious hypothesis to explain these observations of 'non-native' taxa is to couple their occurrence with a major recent inflow of water of Atlantic origin. An analysis of surface currents in the Kattegat (Nielsen 2005) shows evidence of the existence of strong anticyclonic circulation in the upper layer driven primarily by density gradients across the Kattegat-Skagerrak front, and compensating deep water movements in the opposite direction that can, within a time span of a few days, transport North 
Sea/Atlantic water from the Skagerrak to the Sound. It is tempting also to hypothesize that the survival of warm adapted forms in our local waters is recently facilitated by the overall increase in sea water temperature which is also pertinent to the Baltic Sea at large (Fonselius and Valderrama 2003; MacKenzie and Schiedek 2007). There is a clear need to repeat the annual sampling programmes that constitute the core of this paper in order to verify if, and to which extent, the loricate choanoflagellate community (and, by extension, likely also other groups of heterotrophic flagellates) has actually changed during the last decades, or whether communities such as the $20 \mathrm{~m}$ sample from the Sound will still have to be linked to episodic larger scale water transport events.

\section{Species Diversity in a Global Context}

In an attempt to further analyse the uniqueness of the $20 \mathrm{~m} 24$ Sept. 2014 sample, and the Danish inner waters choanoflagellate community at large, we have constructed a species matrix (presence/absence) across 32 geographic sites (Fig. 9). The Elsinore $20 \mathrm{~m}$ sample is located within the 'warm water' cluster and placed next to samples from Kilsfjorden, Southern Norway and offshore central California, as well as Southern Ocean sites such as northern New Zealand, Sydney, Sea of Cortes and the Beagle Channel. Danish samples at large (excluding the $20 \mathrm{~m}$ sample) cluster within the 'cold water' segment together with sites such as the English Channel (Southampton), West Atlantic (Rhode Island), and the Baltic Sea.

\section{Conclusions}

When compiling decadal data that originate from a reasonably well defined cluster of neighbouring stations that largely share the same basic trends in abiotic and biotic variability, it is evident that pronounced and repetitive seasonal successional patterns exist among loricate choanoflagellates. Such patterns in most cases are likely shaped by seasonal variability in environmental conditions such as temperature, or seasonally recurring patterns of larger scale hydrographic flow events which lead to the build-up of more or less predictable seasonal clusters of species. 
The uniqueness of the $20 \mathrm{~m}$ Sept. 2014 sample from the Sound, in terms of species composition, deserves to be highlighted. As discussed above, it is most likely the result of an infrequently occurring major hydrographic event, although it might also be interpreted in the context of climate change, since the bulk of our other sampling in Danish waters was performed several decades ago. Future campaigns in Denmark using the same sampling techniques will be required to differentiate between these two possibilities.

It is evident from molecular barcoding projects, e.g. the Tara Oceans data (de Vargas et al. 2015), that the number of reference choanoflagellate rDNA barcodes with known taxonomy at the genus and/or species level is at present disappointingly low. In order to improve this situation over time and with the purpose of both elaborating our understanding of phylogenetic relationships within the loricate choanoflagellates, as well as maximizing the future analytical value of molecular barcodes with reference to these particular organisms, e.g. in the context of analyses of occurrence patterns, we are currently conducting a number of loricate choanoflagellate field sampling events with a dual morphological and molecular perspective. The community analysis of archived samples, which is the keystone component of this paper, has proved to be a valuable tool in the context of selecting sampling time-windows in search for specific genera and species. 


\section{Methods}

The material from Danish inner waters (Fig. 1) comes from a variety of individual projects carried out over the past four decades and will be summarized below in chronological order.

Sampling from the Isefjord has been a recurrent event over the last four decades. The main sources of material utilized here originate from year-long sampling campaigns conducted in the innermost broad of the fjord system (Tempelkrogen / 1979-80) as well as from \#H (Vellerup Vig) and selected stations in the Isefjord outer broad sampled during 1984-85. Sampling was either from the shore (Tempelkrogen) or utilizing small boats, i.e. a University of Copenhagen dinghy at \#H or a torpedo recovery vessel from the Kongsøre Naval Facility in the Isefjord outer broad.

A large-scale and multifaceted research programme ('HAV 90') was conducted using the University of Copenhagen RV 'Ophelia’ at a station in the southern Kattegat during 1988-89. Samples intended for LM/TEM analysis originate from surface waters and from the fluorescence maximum depth (FM), which is typically coincident with the halocline.

Contour plots of annual trends in temperature and salinity are shown for both collection sites (Fig. 2A-B).

More recently, single event sampling has been conducted in e.g. the Sound (Fig. 1 / Sep. 2014 and Feb. 2015). Sampling was carried out from the University of Copenhagen RV 'Ophelia'. The samples analysed originate from the brackish surface layer $(5 \mathrm{~m})$ and from the full saline deeper waters (20 m). Vertical temperature and salinity profiles are shown in Figure 2C.

Material collected on an ad hoc basis from various sites within the western Baltic/Kattegat region has also been considered with reference to this paper.

The protocol for processing water samples for LM was similar on all sampling occasions. The nanoplankton community was characterized from a prefiltered (usually $20 \mu \mathrm{m}$ ) water sample (0.5-1 l) that was processed by either direct centrifugation or by centrifugation following gentle 
concentration on top of e.g. a $1 \mu \mathrm{m}$ Nuclepore filter. Small droplets of cells from the resuspended final pellet of material were placed on carefully rinsed cover slips. Cells were subsequently fixed for roughly 30 seconds in the vapour from a 1-2\% solution of $\mathrm{OsO}_{4}$. After drying, the cover slips were carefully rinsed in distilled water in order to remove salt crystals. The cover slips were 'air-mounted' by means of four pads of double sticky tape, nail polish or similar adhesive material. The microscopes used were either a Leitz Dialux 20 equipped with Nomarski optics or an Olympus BH-2 equipped with phase contrast optics.

SEM images of cells from the Sound (Figs7A, F, M, 8A-B, D) originate from Au-coated coverslip preparations that were prepared in accordance with the routine described above, and examined in a FEI Quanta 200 ESEM FEG (property of DTU Cen).

Data analysis was performed using the Primer v7 software (Plymouth Routines in Multivariate Ecological Research; Clarke et al. (2014)). We used the wizard to create a shade plot, a visual representation of the data matrix of species versus sites, in which the higher the value in a specific cell, the darker the shade (white represents absence of a species while full black the highest entry in the whole matrix). The settings include a reduction of the species set to the most important 50 species, and square root transformation of the primary 'quantitative' data (relative abundance). After transforming the full matrix, Bray-Curtis similarities are computed among samples and used to determine the ordering and/or clustering of the samples on the $\mathrm{x}$ axis of the shade plot. The definition of similarity among species was the Index of Association (IA).

Complete author citation of loricate choanoflagellate species is provided for in Table 1 . While it has become an established fact that Savillea parva and S. micropora are in fact forms of the same species (Leadbeater 2015) these are for practical reasons treated here as separate taxonomic units. 


\section{Acknowledgements}

Thanks are due to University of Copenhagen colleagues that in various ways have participated in the year-long sampling programmes contributing an essential part of the core data for this paper. We thank colleagues at the University of Copenhagen Marine Biological Section (Elsinore), in particular Per Juel Hansen and Lasse Riemann, for providing us with excellent laboratory facilities during our Sept. 2014 field campaign. We also thank colleagues at the University of Copenhagen Marine Biological Section (Copenhagen), in particular Gert Hansen, for providing us with excellent laboratory facilities during our Feb./March 2015 field campaign. DJR was supported by a postdoctoral fellowship from the Conseil Régional de Bretagne, and the French Government “Investissements d’Avenir” program OCEANOMICS (ANR-11-BTBR-0008).

\section{References}

Azam F, Fenchel T, Field JG, Gray JS, Meyer-Reil LA, Thingstad F (1983) The ecological role of water-column microbes in the sea. Mar Ecol Progr Ser 10:257-263

Bérard-Therriault L, Poulin M, Bossé L (1999) Guide d'identification du phytoplancton marin de l'estuaire et du Golfe du Saint-Laurent incluant également certains protozoaires. Publication Spéciale Canadienne des Sciences Halieutiques et Aquatiques 128: 1-387

Bergesch M, Odebrecht C, Moestrup Ø (2008) Loricate choanoflagellates from the South Atlantic coastal zone $\left(\sim 32^{\circ} \mathrm{S}\right)$ including the description of Diplotheca tricyclica sp. nov. Biota Neotropica 8:111-122 
Booth BC (1990) Choanoflagellates from the subarctic North Pacific Ocean with descriptions of two new species. Can J Zool 68:2393-2402

Clarke KR, Gorley RN, Somerfield PJ, Warwick RM (2014) Change in marine communities: an approach to statistical analysis and interpretation, 3rd edition. PRIMER-E: Plymouth

Daugbjerg N, Vørs N (1992) Preliminary Results from a Small Scale Survey of Marine Protists from Northern Foxe Basin in the Vicinity of Igloolik Island June 1992. In: Søeberg B, Jensen D, Schurmann H, Steffensen JF, Curtis, MA, Vørs N, Daugbjerg N and P Bushnell (eds) Research on Arctic Biology Igloolik Northwest Territories Canada. Copenhagen: HCØ Tryk, University of Copenhagen

de Vargas C, Audic S, Henry N, Decelle J, Mahé F, Logares R, Lara E, Berney C, Le Bescot N, Probert I, Carmichael M et al. (2015) Eukaryotic plankton diversity in the sunlit ocean. Science 348:1261605-1-11

Espeland G, Throndsen J (1986) Flagellates from Kilsfjorden, southern Norway, with description of two new species of Choanoflagellida. Sarsia 71:209-226

Fonselius S, Valderrama J (2003) One hundred years of hydrographic measurements in the Baltic Sea. J Sea Res 49:229-241

Hara S, Takahashi, E (1987) An investigation with electron microscopy of marine choanoflagellates (Protozoa: Choanoflagellida) from Osaka Bay, Japan. I. Re-investigation of Bicosta spinifera, B. minor and Crucispina cruciformis. Bull Plankton Soc Jpn 34:1-13

Hara S, Sheu J, Chen YL, Takahashi E (1997) Choanoflagellates (Sarcomastigophora, Protozoa) from the coastal waters of Taiwan and Japan (II): Species composition and biogeography. Zool Stud 36:98-110 
Hoepffner H, Haas LW (1990) Electron microscopy of nanoplankton from the North Pacific gyre. J Phycol 26:421-439

Leadbeater BSC (1973) External morphology of some marine choanoflagellates from the coast of Jugoslavia. Arch Protistenkd 115:234-252

Leadbeater BSC (1974) Ultrastructural observations on nanoplankton collected from the coast of Jugoslavia and the Bay of Algiers. J Mar Biol Assoc UK 54:179-196

Leadbeater BSC (2015) The Choanoflagellates: Evolution, Biology and Ecology. Cambridge University Press, Cambridge, UK, 315 p

Leakey RJG, Leadbeater BSC, Mitchell E, McCready SMM, Murray AWA (2002) The abundance and biomass of choanoflagellates and other nanoflagellates in waters of contrasting temperature to the north-west of South Georgia in the Southern Ocean. Europ J Protistol 38:333-350

Lee WJ, Brandt SM, Vørs N, Patterson DJ (2003) Darwin’s heterotrophic flagellates. Ophelia 57:63-98

Manton I, Sutherland J, Leadbeater BSC (1975) Four new species of choanoflagellates from arctic Canada. Proc R Soc Lond B 189:15-27

Marchant HJ, Perrin R (1990) Seasonal variation in abundance and species composition of choanoflagellates (Acanthoecidae) at Antarctic coastal sites. Polar Biol 10:499-505

MacKenzie BR, Schiedek D (2007) Long-term sea surface temperature baselines - time series, spatial covariation and implications for biological processes. J Mar Syst 68:405-420

McKenzie CH., Deibel D, Thompson RJ, MacDonald BA, Penney RW (1997) Distribution and abundance of choanoflagellates (Acanthoecidae) in the coastal cold ocean of Newfoundland, Canada. Mar Biol 129:407-416 
Menezes S (2005) Nanoplankton biodiversity in the Pettaquamscutt river estuary, Rhode Island, U.S.A. PhD thesis Univ Rhode Island, 319 p

Moestrup Ø (1979). Identification by electron microscopy of marine nanoplankton from New Zealand, including description of four new species. New Zeal J Bot 17:61-95

Nielsen MH (2005) The baroclinic surface currents in the Kattegat. J Mar Syst 55:97-121

Samuelsson K, Berglund J, Andersson A (2006) Factors structuring the heterotrophic flagellate and ciliate community along a brackish water primary production gradient. J Plankton Res 28:345359

Smith PJ, Hobson LA (1994) Temporal variations in the taxonomic composition of flagellated nanoplankton in a temperate fjord. J Phycol 30:369-375

Thomsen HA (1978) Nanoplankton from the Gulf of Elat (= Gulf of Aqaba) with particular emphasis on choanoflagellates. Isr J Zool 27:34-44

Thomsen HA (1979) Electron microscopical observations on brackish water nannoplankton from the Tvärminne area, S.W. Coast of Finland. Acta Bot Fenn 110:11-37

Thomsen HA (1982) Planktonic choanoflagellates from Disko Bugt, West Greenland, with a survey of the marine nanoplankton of the area. Medd. Grønland, Bioscience 8:3-35

Thomsen HA (1992) Plankton i de indre danske farvande. Havforskning fra Miljøstyrelsen 11

Thomsen HA (2016) Baltic Sea coccolithophores - an overview of findings from the last decades. J Nannoplankton Res (in press)

Thomsen HA, Boonruang P (1983a) Ultrastructural observations on marine choanoflagellates (Choanoflagellida, Acanthoecidae) from the coast of Thailand; species of Apheloecion gen. nov. J Plankton Res 5:729-753 
Thomsen HA, Boonruang P (1983b) A microscopical study of marine collared flagellates

(Choanoflagellida) from the Andaman Sea, S.W. Thailand; species of Stephanacantha gen. nov. and Platypleura gen. nov. Protistologica 19:193-214

Thomsen HA, Boonruang P (1984) A light and electron microscopical investigation of loricate choanoflagellates (Choanoflagellida, Acanthoecidae) from the Andaman Sea, S.W. Thailand and Denmark; species of Cosmoeca gen. n. Zool Scr 13:165-181

Thomsen HA, Buck KR (1991) Choanoflagellate Diversity with Particular Emphasis on the Acanthoecidae. In Patterson DJ, Larsen J (eds) The Biology of Free-living Heterotrophic Flagellates. Systematics Assoc Special Vol 45, Clarendon Press, Oxford, pp 229-254

Thomsen HA, Buck KR, Chavez FP (1991) Choanoflagellates of the central California waters: taxonomy, morphology and species assemblages. Ophelia 33:131-164

Thomsen HA, Garrison DL, Kosman C (1997) Choanoflagellates (Acanthoecidae, Choanoflagellida) from the Weddell Sea, Antarctica. Taxonomy and community structure with particular emphasis on the ice biota; with preliminary remarks on choanoflagellates from Arctic sea ice (North East Water Polynya, Greenland). Arch Protistenkd 148:77-114

Thomsen HA, Østergaard JB, Hansen LE (1995) Loricate choanoflagellates from West Greenland (August 1988) including the description of Spinoeca buckii gen. et sp. nov. Europ J Protistol 31:3844

Thomsen HA, Buck KB, Coale SL, Garrison DL, Gowing MM (1990) Loricate choanoflagellates (Acanthoecidae, Choanoflagellida) from the Weddell Sea, Antarctica. Zool Scr 19:367-387

Tong SM (1997a) Choanoflagellates in Southampton Water including the description of three new species. J Mar Biol Assoc UK 77:929-958 
Tong SM (1997b) Heterotrophic flagellates from the water column in Shark Bay Western Australia. Mar Biol 128:517-536

Tong SM, Nygaard K, Bernard C, Vørs N and Patterson DJ (1998) Heterotrophic flagellates from the water column in Port Jackson Sydney Australia. Europ J Protistol 34:162-194

Vørs N, Buck KR, Chavez FP, Eikrem W, Hansen LE, Østergaard JB, Thomsen HA (1995) Nanoplankton of the equatorial Pacific with emphasis on the heterotrophic protists. Deep-Sea Res 42:585- 602 


\section{Figure legends}

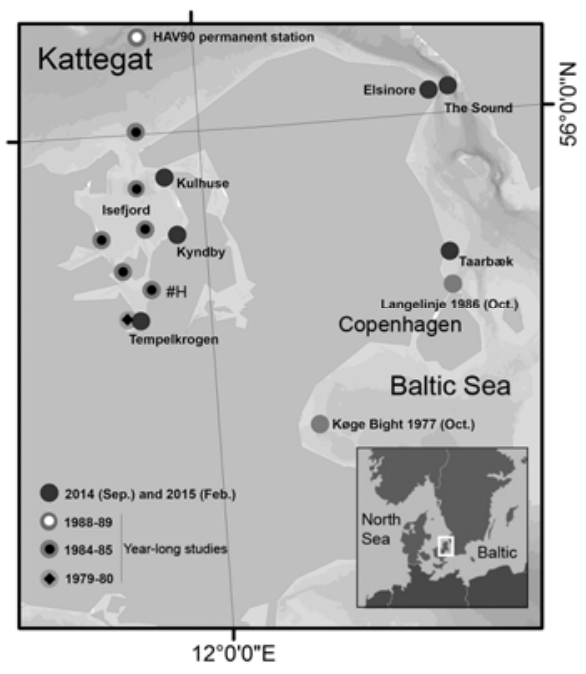

Figure 1. Map showing sampling sites. Symbols indicate sampling time windows. The insert shows the position of the sampling area within a wider geographical context. 

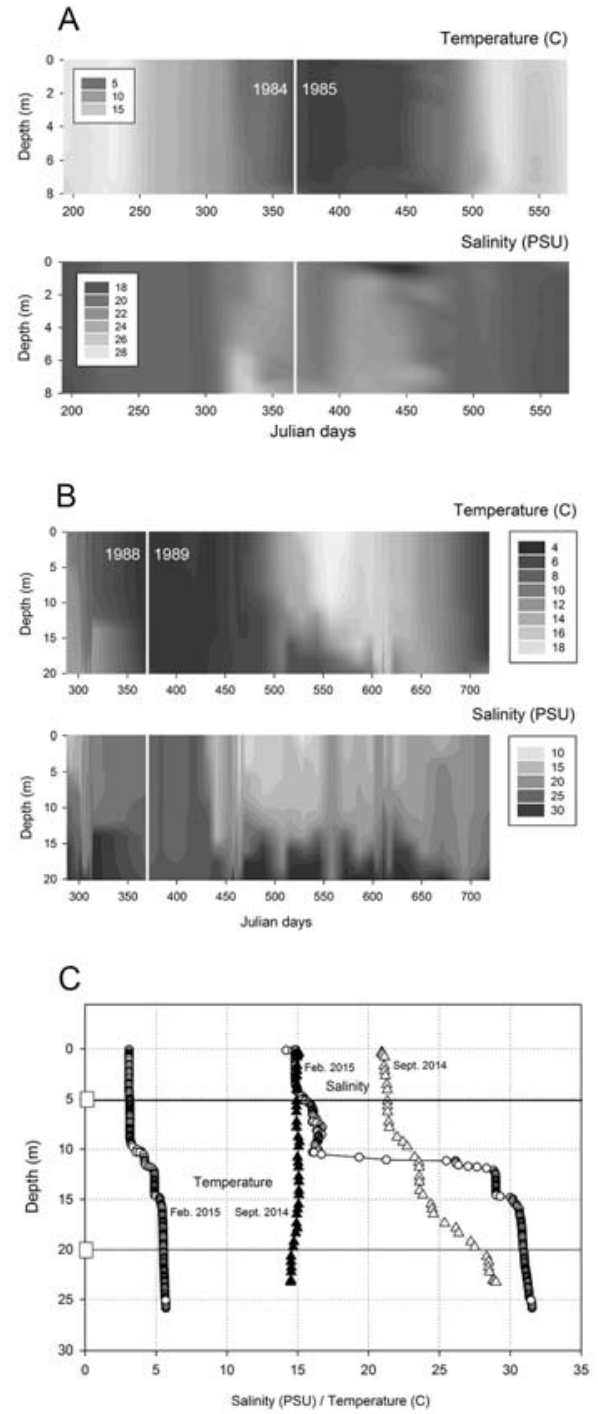

Figure 2. Environmental characteristics (temperature and salinity) of the Isefjord 1984-85 sampling site (A), the 'HAV90' 1988-89 sampling site (B), and vertical profiles (C) from sampling events in the Sound in September 2014 (triangles) and February 2015 (circles). The vertical lines (C) indicate the sampling depths. 


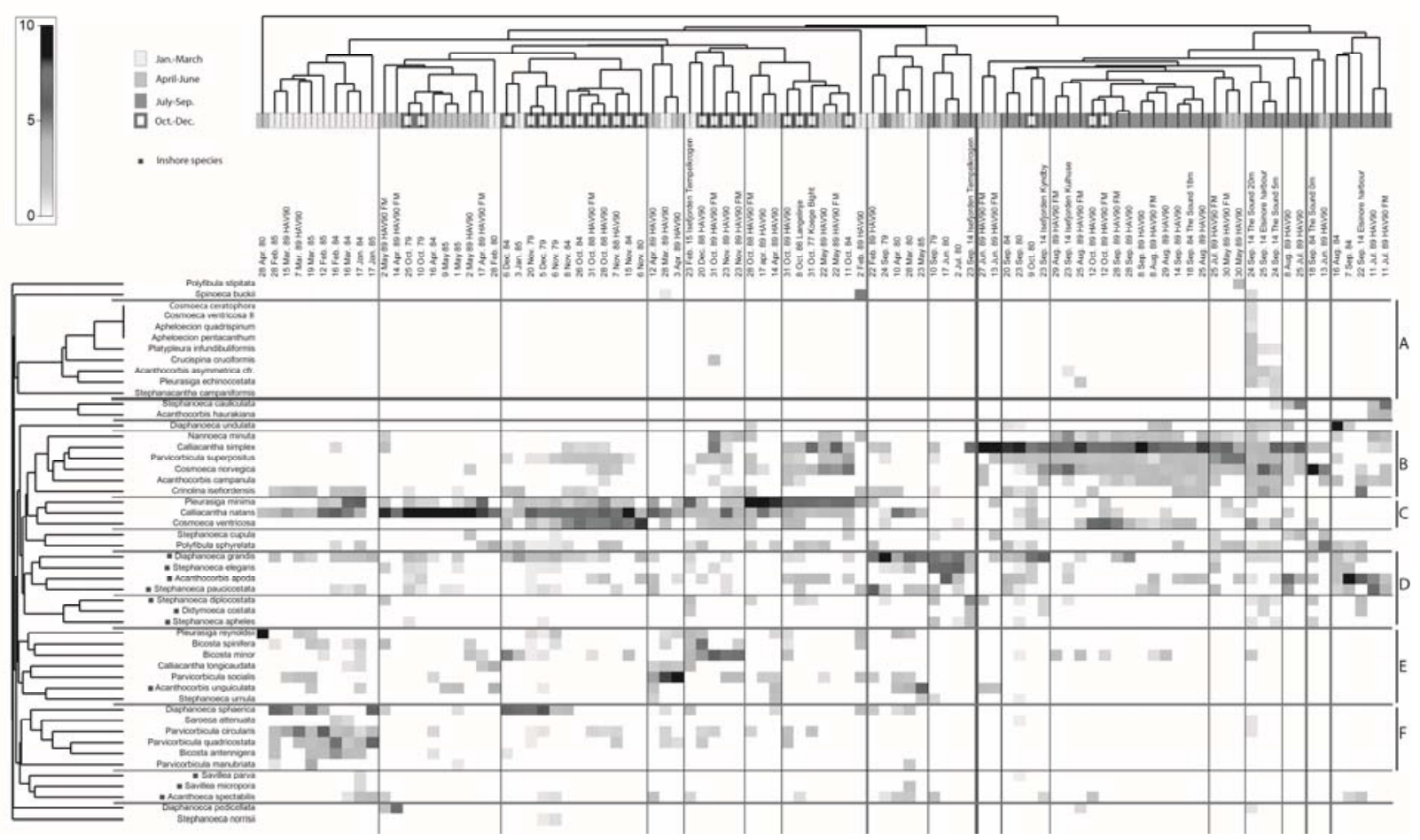

Figure 3. Shade matrix plot (Primer 7) showing relationships among clusters of samples (93) and species (showing only the 50 most important taxa, as calculated by Primer7). Both samples and species are hierarchically clustered independently. Shading intensity within the matrix indicates the transformed relative abundance of each species (a legend is located on the upper left of the plot). Both vertical and horizontal lines are added (thick, medium, and thin) to highlight different groups within the hierarchy and to help identify trends in the material. Species clusters are further identified by letters (A-F). A symbol coding individual samples (4 levels) indicates the annual quarter during which the sample was collected. Inshore species are identified by squares. 

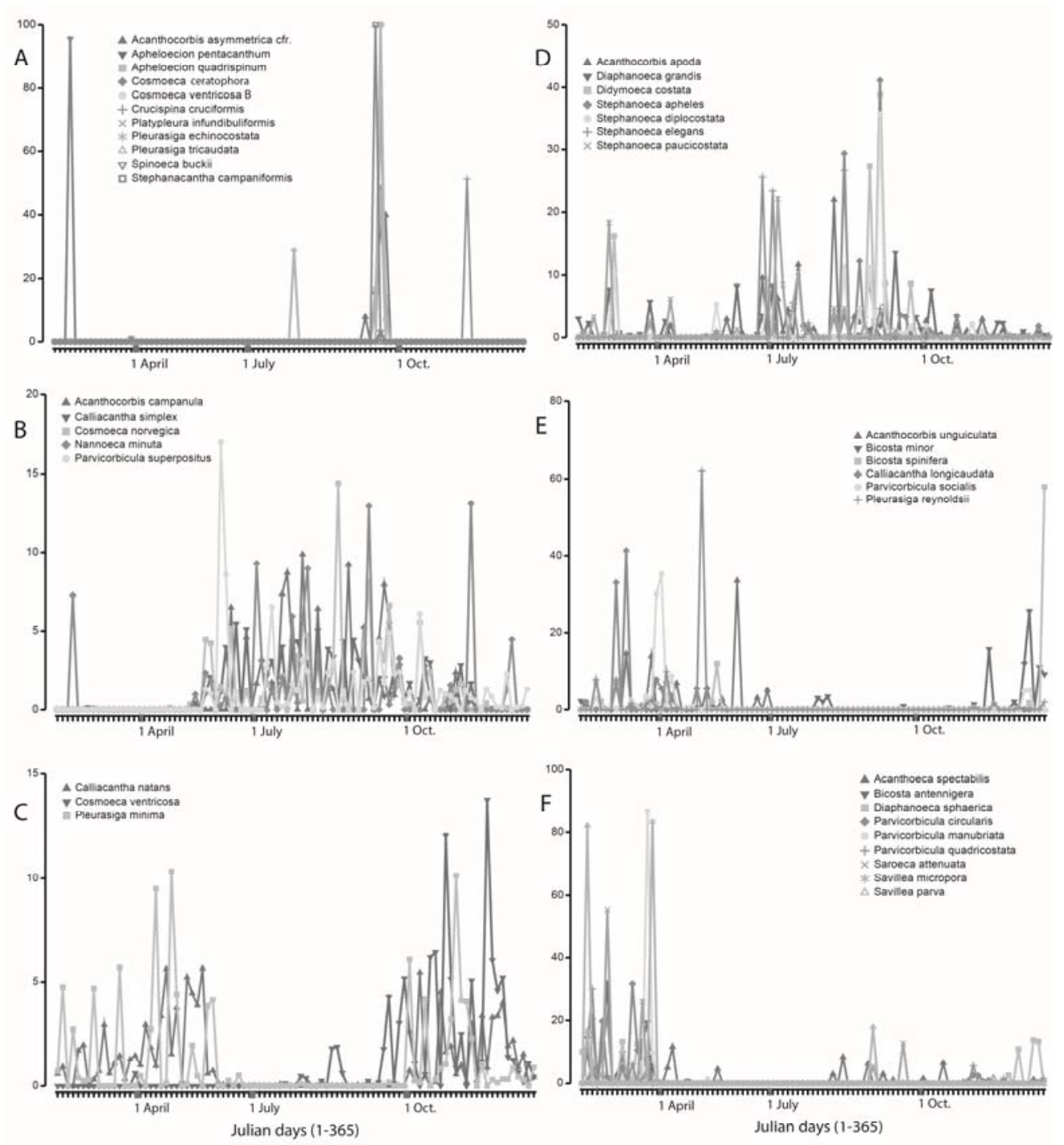

Figure 4. A series of coherence plots showing the annual occurrence pattern of the clusters identified in Figure 3. Notice that the x-axis represents a consecutive line of Julian days sampled, which explains why the quarters indicated are not necessarily of the same size. The y-axis reflects species abundance expressed as a percentage of total relative abundance for the species. The overall picture is that of fairly distinct summer (A, B, D), and winter communities (C, E, F). 


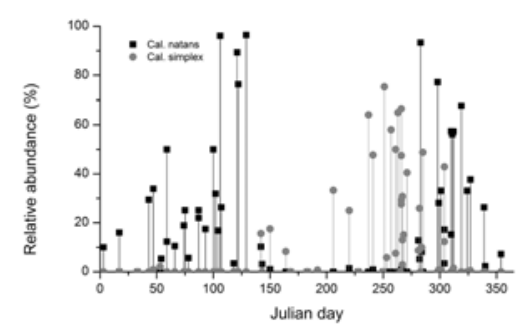

Figure 5. Plot of the seasonal occurrence (relative abundance) of Calliacantha natans and $C$. simplex. Data from the Isefjord and the 'HAV90' stations. 


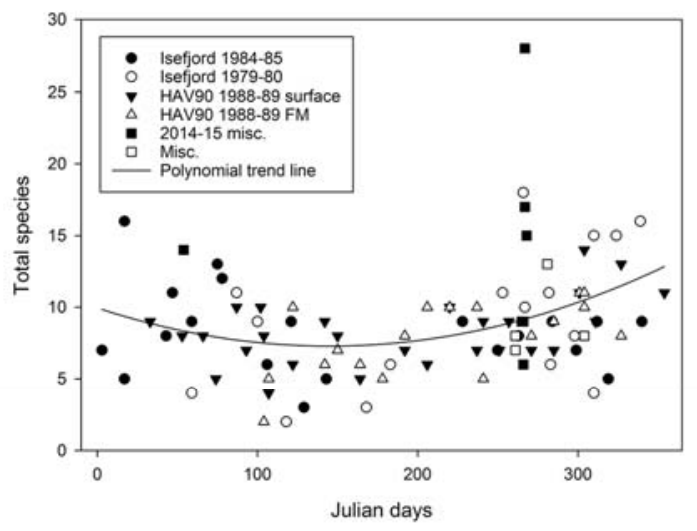

Figure 6. Plot indicating annual trends in number of total species occurring in individual samples (93). A polynomial trend line is added. 

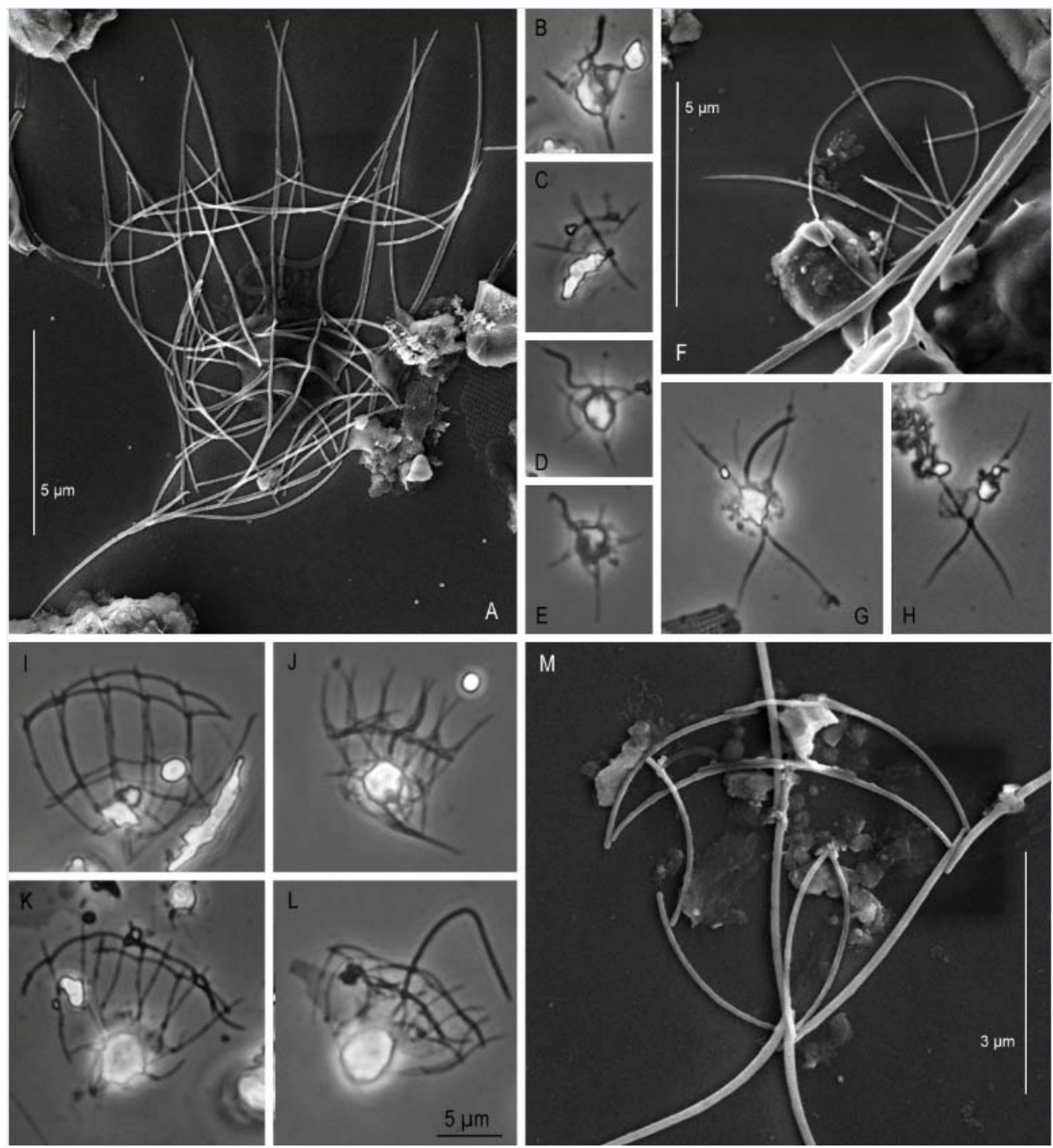

Figure 7. LM (B-E, G-L) and SEM (A, F, M) images of taxa that are either new recordings from

Danish waters or infrequently observed taxa. Acanthocorbis sp. nov. (A, J); Apheloecion

quadrispinum (B, C); Apheloecion pentacanthum (D-F); Crucispina cruciformis (G-H, M);

Cosmoeca ventricosa B (I); Cosmoeca ceratophora (K-L). The scale bar (L) applies to all light micrographs. 

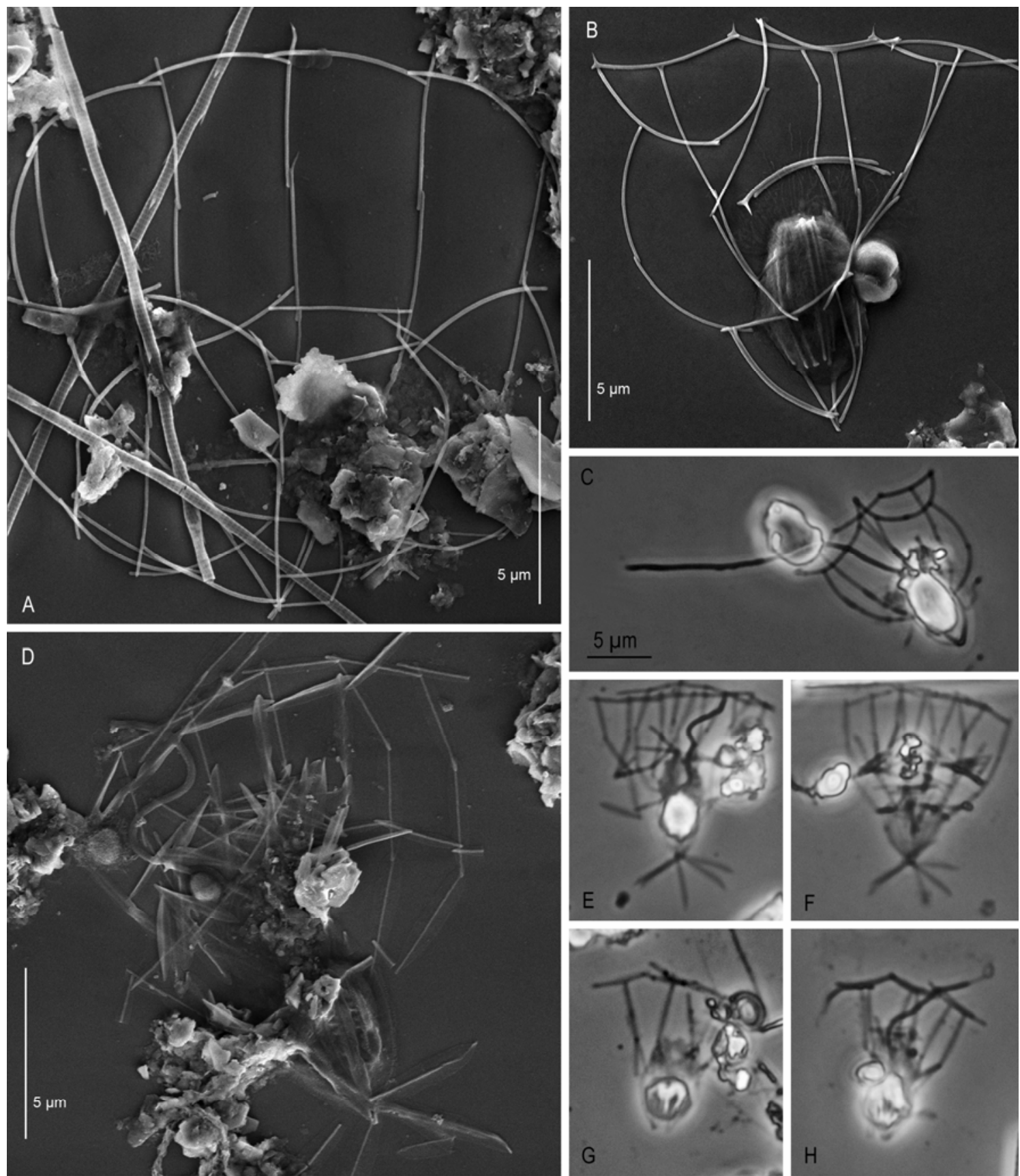

Figure 8. LM (C, E-H) and SEM (A-B, D) images of taxa that are either new recordings from

Danish waters or infrequently observed taxa. Cosmoeca ventricosa B (A); Pleurasiga echinocostata

(B-C); Platypleura infundibuliformis (D-F); Stephanacantha campaniformis (G-H). The scale bar

(C) applies to all light micrographs. 


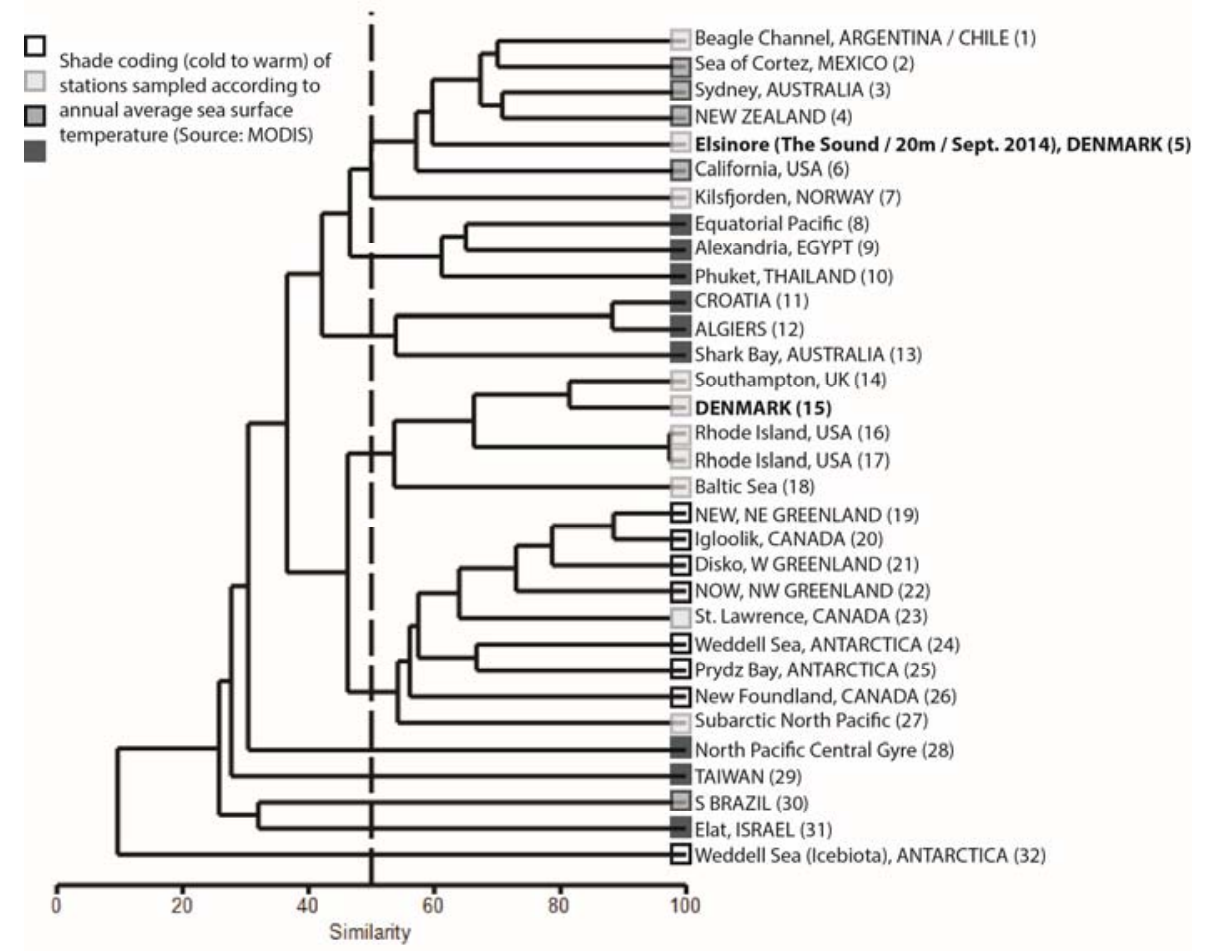

Figure 9. Cluster diagram (presence-absence data matrix; group average; Bray-Curtis similarity) showing relationships among 32 sites worldwide. The vertical dashed line indicates $50 \%$ similarity. The Elsinore data is treated separately from Denmark at large. Symbols (four levels) are used to indicate annual average sea surface temperatures across the sample matrix (source: MODIS); the empty box represents the coldest temperature and the filled box the warmest. Data sources: (3) Tong et al. 1998; (4) Moestrup 1979; (5) this paper; (6) Thomsen et al. 1991; (7) Espeland and Throndsen 1986; (8) Vørs et al. 1995; (10) Thomsen and Boonruang 1983 and subsequent papers; (11) Leadbeater 1973; (12) Leadbeater 1974; (13) Tong 1997b; (14) Tong 1997a; (15) Thomsen 1992; (16) Menezes 2005; (18) Thomsen 1979; (20) Daugbjerg and Vørs 1992; (21) Thomsen 1982; Thomsen et al. 1995; (23) Bérard-Therriault et al. 1999; (24) Thomsen et al. 1990; Thomsen et al. 1997; (25) Marchant and Perrin 1990; (26) McKenzie et al. 1997; (27) Booth 1990; (28) Hoepffner and Haas 1990; (29) Hara et al. 1997; (30) Bergesch et al. 2008; (31) Thomsen 1978; (32) Thomsen et al. 1997; (1, 2, 8, 9, 10, 17, 18, 19, 21, 22, 24) Thomsen unpublished. 


\section{Table Legends}

Table 1. Relative abundance data for loricate species observed during our Sept. 2014 and Feb. 2015 field campaigns. The table also provides taxonomic author citations for all species referred to in this paper. Species identified while randomly scrutinizing a sample are identified by an 'x'.

\begin{tabular}{|c|c|c|c|c|c|c|c|c|c|c|c|c|}
\hline & 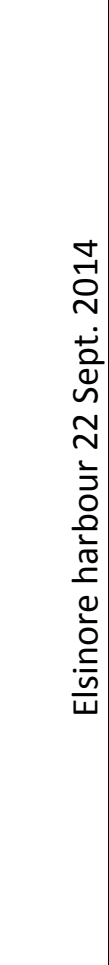 & 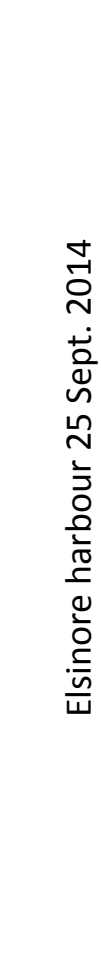 & 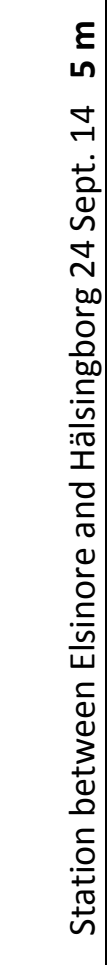 & 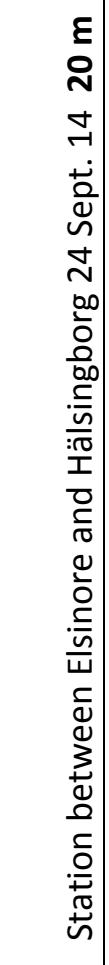 & 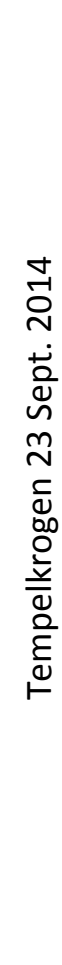 & 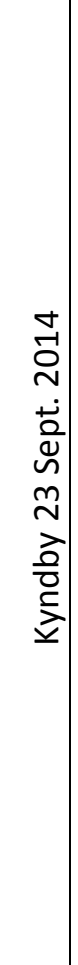 & 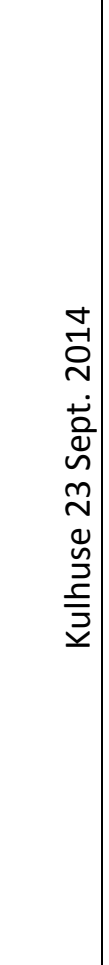 & 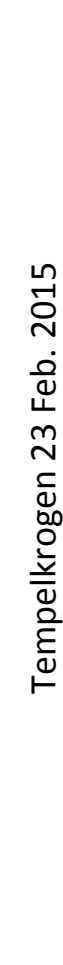 & 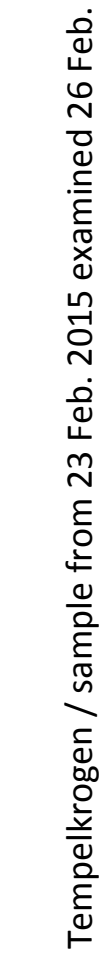 & 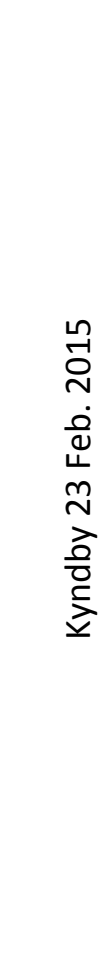 & 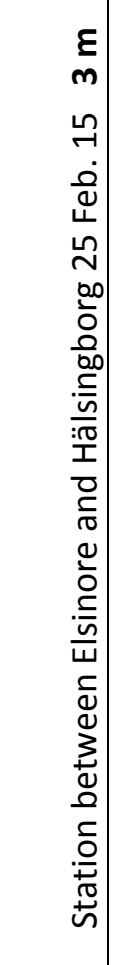 & 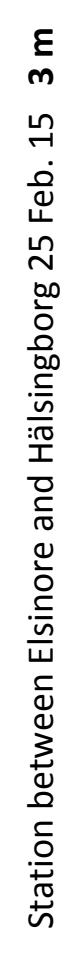 \\
\hline $\begin{array}{l}\text { Acanthocorbis apoda (Leadbeater 1972)Hara \& Takahashi } \\
1984\end{array}$ & 32.9 & & 1.3 & 0.4 & & & 1.8 & & 1.0 & 1.2 & 0.5 & \\
\hline Acanthocorbis apoda cfr. & & & & $\mathrm{x}$ & & & & & & & & \\
\hline Acanthocorbis asymmetrica (Thomsen 1979)Hara \& & & 2.2 & 0.9 & 2.0 & & & 0.4 & & & & & \\
\hline
\end{tabular}




\begin{tabular}{|c|c|c|c|c|c|c|c|c|c|c|c|c|}
\hline Takahashi 1984 cfr. & & & & & & & & & & & & \\
\hline Acanthocorbis campanula (Espeland 1986)Thomsen 1991 & 11.8 & 7.3 & 5.8 & 10.2 & & 6.7 & 0.9 & & & & 0.5 & \\
\hline Acanthocorbis haurakiana Thomsen 1991 & & & $x$ & $x$ & & & & & & & & \\
\hline Acanthoeca spectabilis Ellis 1930 & 2.4 & & & & & 1.1 & & 1.1 & & & & \\
\hline Apheloecion pentacanthum Thomsen 1983 & & & & 3.3 & & & & & & & & \\
\hline Apheloecion quadrispinum Thomsen 1983 & & & & 0.4 & & & & & & & & \\
\hline Bicosta antennigera Moestrup 1979 & & & & & & & & & 0.5 & & & \\
\hline Bicosta minor (Reynolds 1976)Leadbeater1978 & & & & 2.0 & & & & 14.9 & 23.7 & 16.7 & & \\
\hline Bicosta spinifera (Throndsen 1970)Leadbeater 1978 & & & & & & & & 6.4 & 8.6 & 15.4 & 1 & \multirow{22}{*}{ 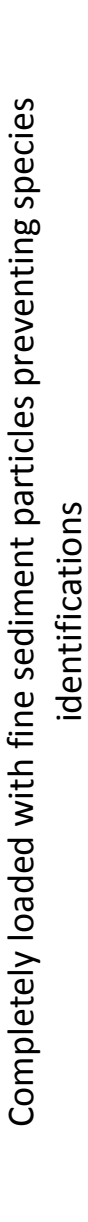 } \\
\hline $\begin{array}{l}\text { Calliacantha longicaudata (Leadbeater 1975)Leadbeater } \\
1978\end{array}$ & & & & & & & & 13.3 & 6.1 & 14.2 & 1 & \\
\hline Calliacantha natans (Grøntved 1956)Leadbeater 1978 & & & & & & & & 5.3 & 1.0 & 4.3 & 3.1 & \\
\hline Calliacantha simplex Manton \& Oates 1979 & & 15.1 & 30.8 & 13.0 & 47.5 & 29.2 & 27.6 & & & & & \\
\hline Cosmoeca norvegica Thomsen 1984 & 1.2 & 32.4 & 21.0 & 15.4 & & 20.2 & 39.6 & 0.5 & 0.5 & & & \\
\hline Cosmoeca ceratophora Thomsen 1984 & & & & 0.8 & & & & & & & & \\
\hline Cosmoeca ventricosa Thomsen 1984 & & 0.6 & 8.5 & 20.3 & & 1.1 & & & & & & \\
\hline Cosmoeca ventricosa 'B' Thomsen 1984 & & & & 0.8 & & & & & & & & \\
\hline Crinolina isefiordensis Thomsen 1976 & 25.9 & 19.6 & 11.2 & 3.7 & & & & $x$ & & & 0.5 & \\
\hline Crucispina cruciformis (leadbeater 1974)Espeland 1986 & & & $x$ & 3.7 & & & & & & & & \\
\hline Diaphanoeca grandis Ellis 1930 & 8.2 & 1.1 & 0.9 & 1.2 & 12.5 & 33.7 & $x$ & 1.1 & & 1.2 & 0.5 & \\
\hline Diaphanoeca pedicellata Leadbeater 1972 & & & & 0.4 & & & & & & & & \\
\hline Diaphanoeca sphaerica Thomsen 1982 & & & & & & & & 3.2 & 2.5 & 4.3 & 0.5 & \\
\hline Diaphanoeca undulata Thomsen 1982 & & 1.7 & 1.3 & 2.4 & & & & & & & & \\
\hline Didymoeca costata (Valkonao 1970)Doweld 2003 & 3.5 & 1.1 & & & 5 & 1.1 & $x$ & 2.1 & & & & \\
\hline Nannoeca minuta (Leadbeater 1972)Thomsen 1988 & & 0.6 & & 3.7 & & & 22.2 & & & & & \\
\hline Parvicorbicula circularis Thomsen 1976 & & & & 0.4 & & & & & & & 1.5 & \\
\hline Parvicorbicula superpositus Both 1990 & & 15.1 & 13.4 & 5.3 & & 5.6 & 6.2 & & & & & \\
\hline Parvicorbicula quadricostata Throndsen 1970 & & & & & & & & & & 0.6 & 1 & \\
\hline Parvicorbicula socialis (Meunier 1010)Deflandre 1960 & & & & & & & & $x$ & & & & \\
\hline $\begin{array}{l}\text { Platypleura infundibuliformis (Leadbeater 1974)Thomsen } \\
1983\end{array}$ & & 0.6 & 0.4 & 2.8 & & & & & & & & \\
\hline Pleurasiga echinocostata Espeland 1986 & & 0.6 & 1.3 & 3.7 & & & & & & & & \\
\hline
\end{tabular}




\begin{tabular}{|c|c|c|c|c|c|c|c|c|c|c|c|c|}
\hline Pleurasiga tricaudata Booth 1990 & & & & 0.4 & & & & & & & & \\
\hline Pleurasiga minima Throndsen 1970 & & & & 1.2 & & & & 32.4 & 52 & 33.3 & 83.5 & \\
\hline Pleurasiga reynoldsii Throndsen 1970 & & & & & & & & 12.2 & 3.5 & 6.8 & 2.1 & \\
\hline Polyfibula elatensis (Thomsen 1978)Manton 1981 cfr. & & $x$ & & & & & & & & & & \\
\hline Polyfibula sphyrelata (Thomsen 1973)Manton 1981 & 7.1 & 1.1 & 0.9 & 0.4 & & & & 0.5 & 0.5 & 1.9 & 1.5 & \\
\hline Saroeca attenuata Thomsen 1979 & & & & 0.4 & & & & $\mathrm{x}$ & & & 1.5 & \\
\hline Savillea micropora (Ellis 1930)Loeblich III 1967 & & & & & & & & $\mathrm{x}$ & & & & \\
\hline Spinoeca buckii Thomsen 1995 & & & & 0.8 & & & & & & & 0.5 & \\
\hline $\begin{array}{l}\text { Stephanacantha campaniformis (Leadbeater } \\
\text { 1973)Thomsen } 1983\end{array}$ & & & 0.9 & $\mathrm{x}$ & & & & & & & & \\
\hline Stephanoeca apheles Thomsen 1991 & & & 0.4 & 0.4 & 5.0 & & & & & & & \\
\hline Stephanoeca cauliculata Leadbeater 1980 & & & 0.4 & $x$ & & & & & & & & \\
\hline Stephanoeca diplocostata Ellis 1930 & 7.1 & 1.1 & 0.4 & 0.4 & 22.5 & 1.1 & 0.4 & 6.4 & & & 0.5 & \\
\hline Stephanoeca elegans (Norris 1965)Throndsen 1974 & & & & $\mathrm{x}$ & 7.5 & & 0.9 & 0.5 & & & & \\
\hline Number of loricas identified & 85 & 179 & 224 & 246 & 40 & 89 & 225 & 188 & 198 & 162 & 194 & 0 \\
\hline Number of species & 9 & 16 & 19 & 33 & 6 & 9 & 11 & 18 & 11 & 11 & 16 & 0 \\
\hline Total from locality & \multicolumn{4}{|c|}{ The Sound: 36} & \multicolumn{3}{|c|}{ Isefjord: 14} & \multicolumn{3}{|c|}{ Isefjord: 21} & \multicolumn{2}{|c|}{$\begin{array}{l}\text { The Sound } \\
16\end{array}$} \\
\hline
\end{tabular}


Table 2. Occurrence data for 'non-native' species collected Sept. 2014 from the Sound (20m). Type localities are in bold face with a shaded background.

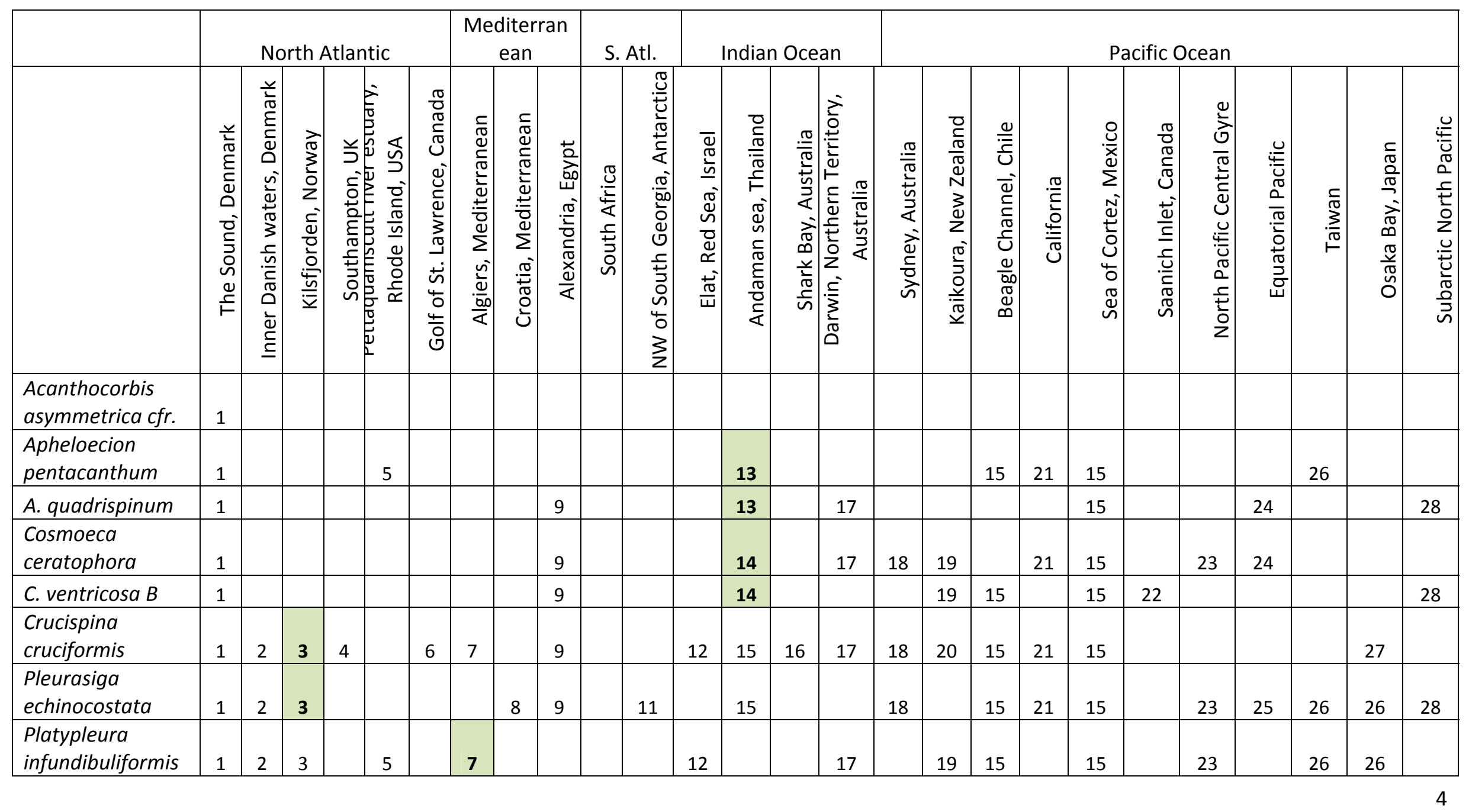




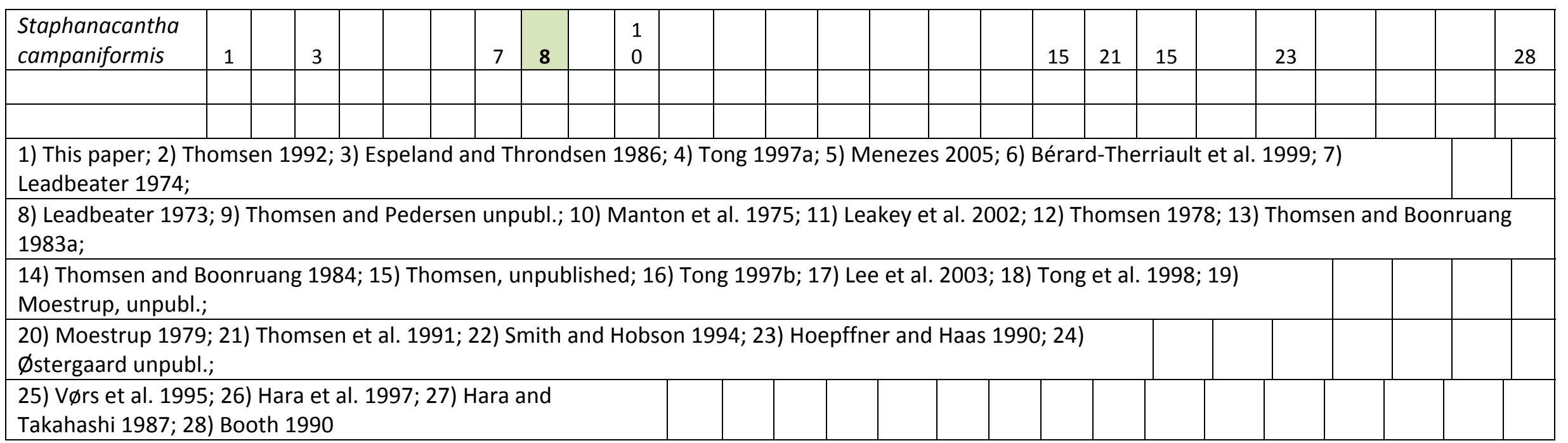

